\title{
BANANA TRUNK FIBERS AS AN EFFICIENT BIOSORBENT FOR THE REMOVAL OF Cd(II), Cu(II), Fe(II) AND Zn(II) FROM AQUEOUS SOLUTIONS
}

\author{
KATHIRESAN SATHASIVAM ${ }^{a, b}$ AND MAS ROSEMAL HAKIM MAS HARIS ${ }^{a}$ \\ ${ }^{a}$ School of Chemical Sciences, Universiti Sains Malaysia, 11800 Minden, Penang, Malaysia. \\ ${ }^{b}$ Department of Materials Science, Faculty of Applied Sciences, AIMST University, 08100 Bedong, Kedah, Malaysia \\ Corresponding author: Mas Rosemal Hakim Mas Haris, School of Chemical Sciences, Universiti Sains Malaysia, Minden, 11800, Penang, Malaysia \\ (Received: November 25, 2009 - Accepted: May 3, 2010)
}

\begin{abstract}
The biosorption of $\mathrm{Cd}(\mathrm{II}), \mathrm{Cu}(\mathrm{II}), \mathrm{Fe}(\mathrm{II})$ and $\mathrm{Zn}(\mathrm{II})$ from aqueous solutions by an agrowaste, namely banana trunk fibers (BTF), was investigated. The effect of $\mathrm{pH}$, contact time, metal ions concentration, adsorbent dose and change in $\left[\mathrm{M}^{2+}\right] /$ biomass were studied at ambient temperature $\left(25^{\circ} \mathrm{C}\right)$. The equilibrium process was described well by the Freundlich isotherm model with adsorption capacity, $\mathrm{K}_{\mathrm{f}}$ of $8.49,2.68,6.58$ and $1.74 \mathrm{mg} / \mathrm{g}$ for $\mathrm{Cd}(\mathrm{II}), \mathrm{Cu}(\mathrm{II}), \mathrm{Fe}(\mathrm{II})$ and $\mathrm{Zn}$ (II), respectively. Kinetic studies showed good correlation coefficients for a pseudo-second-order kinetic model. The BTF were subjected to different chemical modification methods (mercerization, acetylation, formaldehyde treatment, peroxide treatment, stearic acid treatment and sulphuric acid treatment) and the adsorption capacity $\left(\mathrm{q}_{\mathrm{e}}\right.$ ) of each modified BTF for the metal ions was obtained. Our findings hitherto reveal that the $\mathrm{q}_{\mathrm{e}}$ values are practically similar to that of the unmodified BTF confirming that the latter by its nature, that is its chemical composition, is already an efficient biosorbent for the removal of the heavy metal ions.
\end{abstract}

Keywords: Banana Trunk Fibers; Agrowaste; Biosorption; Heavy Metal Ions; Isotherm

\section{INTRODUCTION}

Industrialization has enhanced the degradation of our environment through the discharge of wastewaters. This has resulted in significant amounts of heavy metal ions such as $\mathrm{Cd}(\mathrm{II}), \mathrm{Cu}(\mathrm{II}), \mathrm{Fe}(\mathrm{II})$ and $\mathrm{Zn}(\mathrm{II})$ being deposited into our ecosystems. These metals are not biodegradable and known to cause severe dysfunction of the kidney, reproductive system, liver, brain and central nervous system $^{2}$. Several methods for removing heavy metal ions such as chemical precipitation, electrodeposition, ion exchange, reverse osmosis and adsorption have been used to treat wastewater. Of these methods, chemical precipitation is the most economic but is inefficient for dilute solution. Electrodepostion, ion exchange and reverse osmosis are generally effective, but have rather high maintenance and operation costs and subject to fouling. Biosorption, a process that utilizes biomass ${ }^{3}$ for the decontamination of metal-containing effluents is a promising alternative. Low-cost natural sorbents such as cork and yohimbe bark $^{4}$, spent grain 5 , peanut hull pellets ${ }^{6}$, rice milling by-products ${ }^{7}$, grape stalk waste $^{8}$, pectin rich fruit wastes ${ }^{9}$ and biowaste from fruit juice industry ${ }^{10}$.

Banana plants are of the family Musacease and cultivated primarily for their fruit. As such, after harvesting the fruit, the matured pseudostems are generally disposed at a landfill or left to decompose slowly in a plantation field. The composition of a typical BTF obtained by elemental analysis, as determined by Bilba et al, ${ }^{11}$ is as follows: Cellulose $(31.27 \pm 3.61 \%)$, Hemicellulose (14.98 $\pm 2.03 \%$ ), Lignin $(15.07 \pm 0.66 \%$ ), Extractives $(4.46 \pm 0.11 \%$ ), (Moisture $9.74 \pm 1.42 \%)$ and Ashes $(8.65 \pm 0.10 \%)$.

The aim of the study is to evaluate the efficiency of the removal of $\mathrm{Cd}(\mathrm{II}), \mathrm{Cu}(\mathrm{II}), \mathrm{Fe}(\mathrm{II})$ and $\mathrm{Zn}$ (II) from aqueous solutions by unmodified BTF. The effect of various operating parameters such as $\mathrm{pH}$, contact time, metal ions concentration, adsorbent dose and change in $\left[\mathrm{M}^{2+}\right] /$ biomass was studied. The adsorption isotherm study was also carried out on two isotherm models, namely Langmuir and Freundlich. The adsorption capacity were determined and compared by first and second order kinetic models.

\section{MATERIALS AND METHODS}

\section{Biosorbent material}

BTF from the family of Musa acuminate $x$ balbisiana Colla (ABB Group) cv 'Pisang Awak' were obtained locally, Penang, Malaysia. The pseudostems were chopped into cubes of average size of $2 \mathrm{~cm} \times 2 \mathrm{~cm}$. The cubes were submerged in boiling water for $1 \mathrm{hr}$ and then dried in an oven at $70{ }^{\circ} \mathrm{C}$ until a constant weight was obtained. The resulting material was ground using a Waring Commercials high speed blender and sieved to isolate fibers of the size 212 - 350 micron. The native metal content the BTF were observed by using a scanning electron microscopy (SEM-EDX) machine Model Leica Cambridge AS-360 at an accelerating voltage $15 \mathrm{kV}$. Prior to examination, a surface of specimen was coated with a thin layer of gold approximately $30 \mathrm{~nm}$ using Sputter Coater Polaron SC 515.

\section{Metal Solution}

$\mathrm{Cd}(\mathrm{II}), \mathrm{Cu}(\mathrm{II}), \mathrm{Fe}(\mathrm{II})$ and $\mathrm{Zn}(\mathrm{II})$ standard solutions $(1000 \pm 2 \mathrm{mg} / \mathrm{L})$ from Merck were diluted to desired concentrations for Atomic Absorption Spectroscopy (AAS) analysis. The experiment was conducted at $\mathrm{pH}$ value range 2 to 6 . The $\mathrm{pH}$ was adjusted by adding appropriate amount of either 0.1 $\mathrm{M} \mathrm{NaOH}$ or $0.1 \mathrm{M} \mathrm{HCl}$ solution before each experiment

\section{Equilibrium studies}

Adsorption experiments were carried out by adding $0.2 \mathrm{~g}$ of sorbent into $250-\mathrm{mL}$ Erlenmeyer flasks containing $50 \mathrm{~mL}$ solutions of different concentrations $(1,10$ and $100 \mathrm{mg} / \mathrm{L})$ of metal ions. The temperature was controlled at $25{ }^{\circ} \mathrm{C}$. Agitation was provided at $150 \mathrm{rpm}$ for $180 \mathrm{~min}$. The initial and equilibrium metal concentrations were determined by absorbance measurement using the Atomic absorption Spectroscopy (AAnalyst 700, Perkin-Elmer, Waltham, MA, USA). When the equilibrium was established, the supernatant was carefully filtered through Whatman filter paper (No. 1) which was pre-saturated with distilled water. It is worthwhile to note that no adsorption of the metals occurred on the filter paper: a comparative study was done by measuring the concentration of the metal solution before and after filtering, and the result showed insignificant variation of concentration of the metal solution meaning that the amount of the metals adsorbed on the filter paper, if any, was negligible. It was then computed to metal concentration using standard calibration curve. The adsorption at equilibrium, $q_{\mathrm{e}}(\mathrm{mg} / \mathrm{g})$, was calculated using equation (1).

$$
q_{e}=\left(C_{o}-C_{e}\right) \frac{V}{W}
$$

where $C_{\mathrm{o}}$ and $C_{\mathrm{e}}(\mathrm{mg} / \mathrm{L})$ are the liquid-phase concentrations of metals at initial and equilibrium, respectively. $V$ is the volume (L) of the solution and $W$ is the weight $(\mathrm{g})$ of dry sorbent. For the determination of rate of sorption and the sorption equilibrium time, the residual metal in the supernatant was determined by allowing metal-BTF contact for different periods between 5 and $180 \mathrm{~min}$. The metal-BTF sorption suspension was equilibrated at different $\mathrm{pH}$ values of $2-6$. For the adsorption isotherms studies, metal concentrations used for sorption ranged between 1 and $500 \mathrm{mg} / \mathrm{L}$. The quantity of biomass was varied between 0.1 and $1.0 \mathrm{~g}$ to determine the BTF required for optimum level of sorption.

\section{Treatments of Banana Trunk Fibers}

The BTF were modified according to the methods reported in literature: (i) mercerization, the fibers were immersed in $5 \% \mathrm{NaOH}$ solution for $48 \mathrm{hr}$ at 25 ${ }^{\circ} \mathrm{C}^{12}$, (ii) acetylation, the mercerized fibers were soaked in glacial acetic acid for $1 \mathrm{hr}$, separated by decantation and then soaked in acetic anhydride containing 2 drops of concentrated $\mathrm{H}_{2} \mathrm{SO}_{4}$ for $2 \mathrm{~min}^{13}$, (iii) formaldehyde treatment, using $1 \%$ formaldehyde in the weight to volume ratio of $1: 5$ at $50{ }^{\circ} \mathrm{C}$ for $4 \mathrm{hr}^{14}$, 
(iv) peroxide treatment, the mercerized fibers $(30 \mathrm{~g})$ were immersed in $1 \mathrm{~L}$ of a $6 \%$ solution of benzoyl peroxide in acetone for $30 \mathrm{~min}^{13}$, (v) stearic acid treatment, a mixture containing $1.0 \mathrm{~g}$ of the fibers, $0.2 \mathrm{~g}$ of stearic acid, 2 drops of concentrated $\mathrm{H}_{2} \mathrm{SO}_{4}$ in $100 \mathrm{~mL}$ of $\mathrm{n}$-hexane was refluxed in a Dean-Stark apparatus at $65{ }^{\circ} \mathrm{C}^{2}$ for $6 \mathrm{hr}^{15}$, and (vi) sulphuric acid treatment, $1: 1$ weight ratio of the fibers : concentrated $\mathrm{H}_{2} \mathrm{SO}_{4}$ was heated in a muffle furnace for $24 \mathrm{~h}$ at $150{ }^{\circ} \mathrm{C}^{14}$. All resulting fibers were washed ample amount of water till a pH close to neutral was obtained.

\section{RESULTS AND DISCUSSION}

\section{Elemental and Surface Area Analysis}

The results obtained by energy dispersive X-ray (EDX) analysis of BTF are presented in Figure 1. It shows that BTF contained several elements such as carbon $(40.25 \%)$, oxygen $(55.85 \%)$, potassium $(2.41 \%)$, calcium $(1.49 \%)$ and the presence of the metals understudy were not observed. Surface area of BTF was characterized according to method described by Horsfall and Spiff ${ }^{16}$ and was found to be $28.75 \pm 1.57 \mathrm{~m}^{2} / \mathrm{g}$.

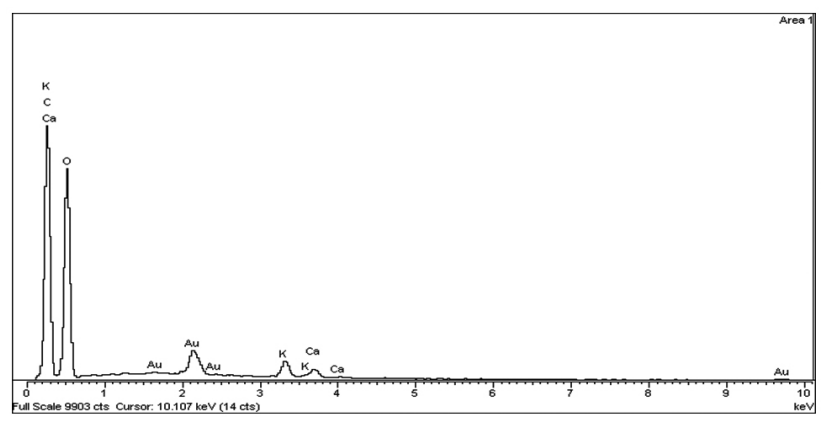

Figure 1: Energy dispersive X-ray (EDX) scan of BTF

\section{Effect of $\mathrm{pH}$ on metal ion sorption}

$\mathrm{pH}$ of solution has been identified as the most important variable governing metal ions uptake because it influences the ionization of functional groups at the surface of a sorbent and hydrogen ions themselves may compete strongly with the adsorbates ${ }^{17,18}$. Hence, comparative studies on metal ions uptake must be carried out in solutions of similar $\mathrm{pH}$ value as any variation in the $\mathrm{pH}$ can drastically change the adsorption capacity of a sorbent ${ }^{19}$. With this in view, the uptake of $\mathrm{Cd}(\mathrm{II}), \mathrm{Cu}(\mathrm{II}), \mathrm{Fe}(\mathrm{II})$ and $\mathrm{Zn}$ (II) by BTF was investigated at various $\mathrm{pH}$ values (Figure 2). At the $\mathrm{pH} 2$, it was observed that the sorptions were poor. This was attributed to the active sites being widely protonated which limits the adsorbing sites for the metal ions ${ }^{20}$. In the $\mathrm{pH}$ range of $3-$ 5 , a prominent increase in the sorptions was observed. The increase in metal removal as the $\mathrm{pH}$ increases can be explained on the basis of decrease in competition between protons and metal cations for the same binding sites ${ }^{21}$. Furthermore, the decrease in the positive surface charges resulting in a lower electrostatic repulsion between the surface and metal ions ${ }^{22}$. Further increase in sorptions was insignificant as the optimum biosorption for all the four metals was reached at about $\mathrm{pH} 5$.

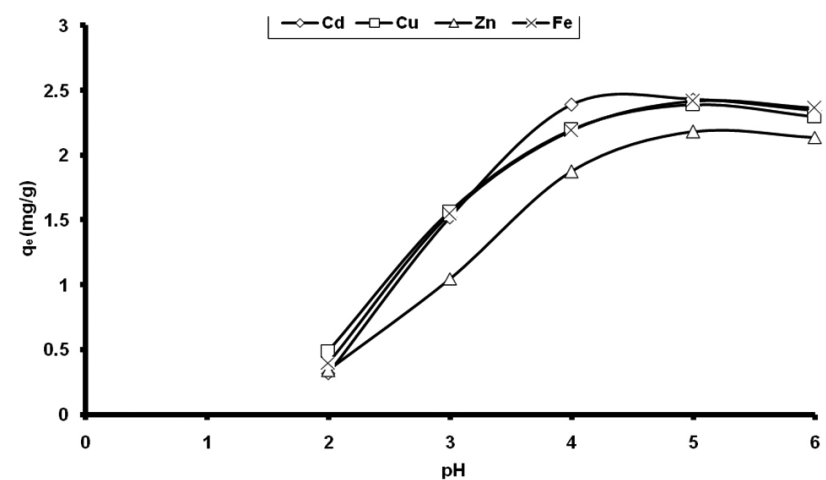

Figure 2:. Dependence of $\mathrm{q}_{\mathrm{e}}$ of $\mathrm{Cd}(\mathrm{II}), \mathrm{Cu}(\mathrm{II}), \mathrm{Fe}(\mathrm{II})$ and $\mathrm{Zn}(\mathrm{II})$ with $\mathrm{pH}$ at $25^{\circ} \mathrm{C}$ (concentration $=10 \mathrm{mg} / \mathrm{L}$, volume $=50 \mathrm{~mL}$, BTF dosage $=0.2 \mathrm{~g}$, agitation speed $=150 \mathrm{rpm}$ and contact time $=120 \mathrm{~min}$ )
Effect of contact time and metal concentration on metal adsorption

Figure 3 illustrates the time-course studies on sorption of $\mathrm{Cd}(\mathrm{II}), \mathrm{Cu}(\mathrm{II})$, $\mathrm{Fe}(\mathrm{II})$ and $\mathrm{Zn}(\mathrm{II})$ that were performed by contacting $10 \mathrm{mg} / \mathrm{L}$ of the solutions containing metal ions at $\mathrm{pH} 5$ with $0.2 \mathrm{~g}$ of BTF in $50 \mathrm{~mL}$ of the solutions. All the four metal ions showed a fast rate sorption during the initial $15 \mathrm{~min}$ (first stage) and the equilibrium (second stage) was reached at about 60 mins. The two-stage sorption, the first stage which is quantitatively predominant and the second slower stage which is quantitatively insignificant, has been extensively reported in literature ${ }^{23}$. The rapid stage is attributed to the abundant availability of active sites on the biomass and with the gradual occupancy of these sites, the sorption becomes less efficient in the slower stage ${ }^{24}$. The adsorption capacity $\left(\mathrm{q}_{\mathrm{e}}\right.$ ) for $\mathrm{Cd}(\mathrm{II}), \mathrm{Cu}(\mathrm{II}), \mathrm{Fe}(\mathrm{II})$ and $\mathrm{Zn}(\mathrm{II})$ of $2.43,2.39,2.42$ and $2.18 \mathrm{mg} / \mathrm{g}$, respectively. These results are in keeping with conclusion by Romera et al., ${ }^{25}$ Pejic et $\mathrm{al}^{26}$ and Nasernejad et $\mathrm{al}^{27}$. The uptake level of the metal ions can be explained, similar to that provided by Okieimen et al. ${ }^{28}$ and Ricordel et al. ${ }^{29}$ in terms of (i) the difference in the ionic size of metals, (ii) the nature and distribution of active groups on the biosorbent, (iii) the mode of interaction between the metal ions and the biosorbent (iv) hydration energy, (v) ionic mobility and (vi) diffusion coefficient.

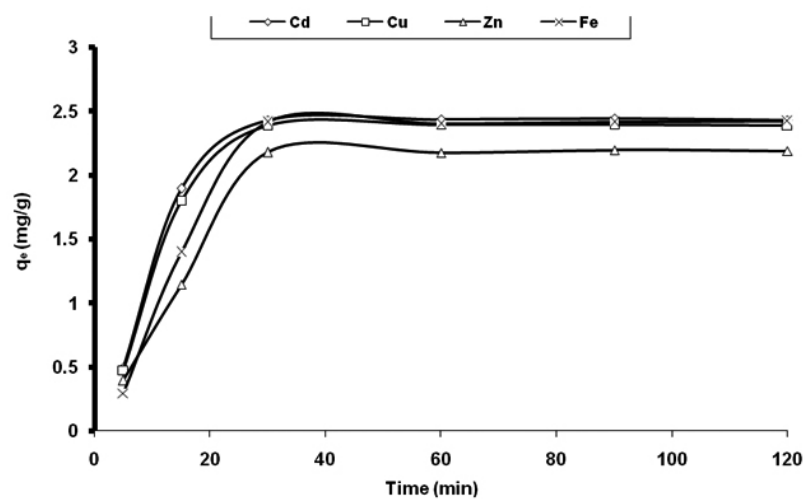

Figure 3: Dependence of $\mathrm{q}_{\mathrm{e}}$ of $\mathrm{Cd}(\mathrm{II}), \mathrm{Cu}(\mathrm{II}), \mathrm{Fe}(\mathrm{II})$ and $\mathrm{Zn}(\mathrm{II})$ with time at $25{ }^{\circ} \mathrm{C}$ (concentration $=10 \mathrm{mg} / \mathrm{L}$, volume $=50 \mathrm{~mL}$, BTF dosage $=0.2 \mathrm{~g}$, agitation speed $=150 \mathrm{rpm}$ and $\mathrm{pH}=5$ )

\section{Optimization of amount of adsorbent}

This adsorption study was carried out with $10 \mathrm{mg} / \mathrm{L}$ metal solution at $\mathrm{pH} 5$ in an orbital shaker agitated at $150 \mathrm{rpm}$ with $50 \mathrm{~mL}$ of the metal ions solution in a $250 \mathrm{~mL}$ Erlenmeyer flask. Results shown in Figure 4 indicate that the adsorbent dosage apparently increases proportionately to the availability of the adsorbent sites. The increase of adsorbent sites and surface area of contact with the metals increases the amount of metal uptakes and consequently leads to a better adsorption. This observed trend is mainly due to the increase in sorptive surface area and availability of more adsorption sites.

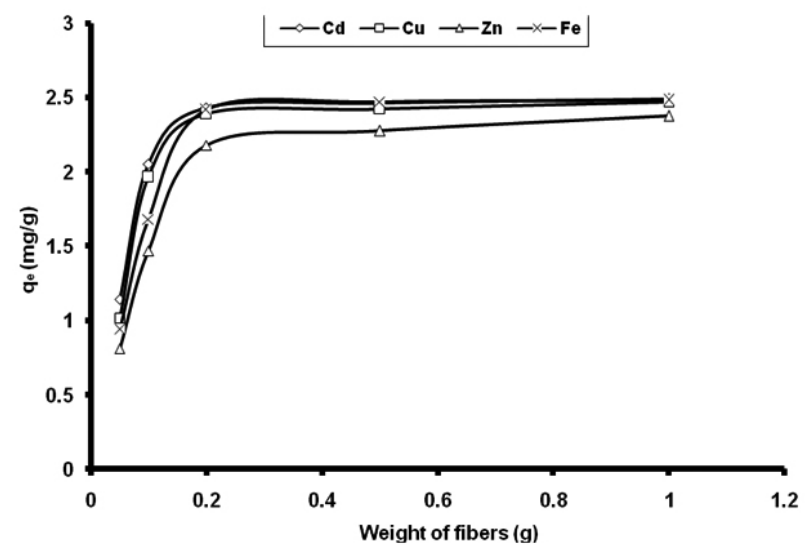

Figure 4: Dependence of $\mathrm{q}_{\mathrm{e}}$ of $\mathrm{Cd}(\mathrm{II}), \mathrm{Cu}(\mathrm{II}), \mathrm{Fe}(\mathrm{II})$ and $\mathrm{Zn}$ (II) with weight of fibers $(\mathrm{g})$ at $25{ }^{\circ} \mathrm{C}$ (concentration $=10 \mathrm{mg} / \mathrm{L}$, volume $=50 \mathrm{~mL}$, agitation speed $=150 \mathrm{rpm}$, time $=60 \mathrm{~min}$ and $\mathrm{pH}=5$ ) 


\section{Concentration dependent study}

The experimental results of the sorption of the metals on BTF at various concentrations are shown in Figure 5. The uptake rate of the metal ions will increase along with increasing concentration if the amount of biomass is kept unchanged. At low concentrations metals adsorb by available sites and with increasing metal concentrations the sites become saturated. The adsorption experiments related to the concentration of metals were carried out over a range of $1-500 \mathrm{mg} / \mathrm{L}$ at $\mathrm{pH} 5$ using $0.2 \mathrm{~g}$ of the fibers in $50 \mathrm{~mL}$ of metal ion solutions with an agitation speed of $150 \mathrm{rpm}$. The adsorption capacity of $\mathrm{Cd}(\mathrm{II}), \mathrm{Cu}(\mathrm{II}), \mathrm{Fe}(\mathrm{II})$ and $\mathrm{Zn}$ (II) increased from 0.24 to $20.82,0.22$ to 23.18 , 0.22 to 22.67 and 0.19 to $22.23 \mathrm{mg} / \mathrm{g}$, respectively. The metal concentration provides the necessary driving force to overcome the resistances to the mass transfer of metal between the aqueous and the solid phases. The increase in concentration also enhances the interaction between metal and the sorbent Therefore, an increase in concentration of the metals enhances the adsorption uptake of metal ions. This indicates that the metal ions concentration plays an important role in the adsorption capacity of metal onto the sorbent. It was also observed that the $\mathrm{q}_{e}$ value increases as the $\mathrm{C}_{\mathrm{e}}$ value increased ${ }^{16}$. It is also worthwhile to note that the $q$ of all the four metal ions were steep at lower equilibrium concentration which is desirable for a sorbent to possess a high affinity for the sorbate species ${ }^{30}$.

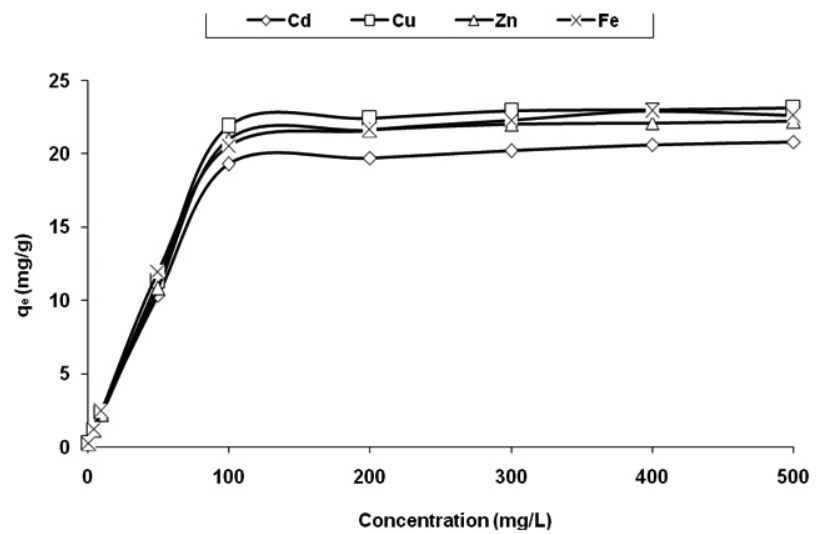

Figure 5: Dependence of $\mathrm{q}_{\mathrm{e}}$ of $\mathrm{Cd}(\mathrm{II}), \mathrm{Cu}(\mathrm{II}), \mathrm{Fe}(\mathrm{II})$ and $\mathrm{Zn}$ (II) with concentration $(\mathrm{mg} / \mathrm{L})$ at $25^{\circ} \mathrm{C}(\mathrm{BTF}$ dosage $=0.2 \mathrm{~g}$, volume $=50 \mathrm{~mL}$, agitation speed $=150 \mathrm{rpm}$, time $=60 \mathrm{~min}$ and $\mathrm{pH}=5$ )

\section{Effect of change in $\left[\mathrm{M}^{2+}\right] /$ biomass}

Various $\left[\mathrm{M}^{2+}\right] /$ biomass ratio were obtained by increasing the mass of BTF while the concentration and volume of the metal ions solution are kept constant. The quantity of BTF was varied between 0.5 and $20 \mathrm{~g}^{-1}$ to determine the optimum quantity of biomass needed for maximum sorption. From $10 \mathrm{mg} / \mathrm{L}$ metal ion solution at $\mathrm{pH} 5$, the $\mathrm{q}_{\mathrm{e}}$ of $\mathrm{Cd}(\mathrm{II}), \mathrm{Cu}(\mathrm{II}), \mathrm{Fe}(\mathrm{II})$ and $\mathrm{Zn}$ (II) of 1.21 , $1.19,1.26$ and $1.05 \mathrm{mg} / \mathrm{g}$, respectively achieved using $10 \mathrm{~g} \mathrm{l}^{-1}$ BTF. Further increase in the BTF weight to $20 \mathrm{~g} \mathrm{l}^{-1}$ increased the adsorption capacity. Table 1 indicates the change in $\left[\mathrm{M}^{2+}\right]$ biomass based on the concentration of the metal solution. The results obtained indicate a decrease in $\left[\mathrm{M}^{2+}\right] /$ biomass. This is attributed to an increase in the adsorption of these metal ions due to the increase of BTF biomass. The increase in BTF biomass increases the adsorption surface area of the biomass ${ }^{31}$. The obtained results are in keeping with the conclusion by Saeed et al ${ }^{32}$.

Table 1: Effect of change in $\left[\mathrm{M}^{2+}\right] /$ biomass ratio on biosorption of $\mathrm{Cd}(\mathrm{II})$, $\mathrm{Cu}(\mathrm{II}), \mathrm{Fe}(\mathrm{II})$ and $\mathrm{Zn}(\mathrm{II})$ (metal concentration $=10 \mathrm{mg} / \mathrm{L}, \mathrm{pH}$, volume $=0.2$ $\mathrm{L}$, agitation speed $=150 \mathrm{rpm}$, time $=60 \mathrm{~min})$.

\begin{tabular}{|c|c|c|c|c|c|}
\hline \multirow{2}{*}{$\begin{array}{c}\text { Biomass } \\
\text { Concentration } \\
(\mathrm{g} / \mathrm{L})\end{array}$} & \multirow{2}{*}{$\begin{array}{c}{\left[\mathrm{M}^{2+}\right] /} \\
\text { biomass } \\
(\mathrm{mg} / \mathrm{g})\end{array}$} & \multicolumn{4}{|c|}{ Metal adsorbed, $\mathrm{q}_{\mathrm{e}}(\mathrm{mg} / \mathrm{g})$} \\
\cline { 3 - 6 } & & $\mathrm{Cd}(\mathrm{II})$ & $\mathrm{Cu}(\mathrm{II})$ & $\mathrm{Fe}(\mathrm{II})$ & $\mathrm{Zn}(\mathrm{II})$ \\
\hline 1 & 10 & 8.97 & 8.62 & 8.90 & 8.16 \\
\hline 2 & 5 & 4.46 & 4.38 & 4.41 & 4.08 \\
\hline 4 & 2.5 & 2.43 & 2.39 & 2.42 & 2.18 \\
\hline 10 & 1 & 1.21 & 1.19 & 1.26 & 1.05 \\
\hline 20 & 0.5 & 0.46 & 0.48 & 0.65 & 0.41 \\
\hline
\end{tabular}

\section{Adsorption Isotherms}

Langmuir isotherm model assumes the uniform energies of adsorption onto the surface and no transmigration of adsorbate in the plane of the surface ${ }^{33}$. The linear form of Langmuir isotherm equation is given in equation (2).

$$
\frac{C_{e}}{q_{e}}=\frac{1}{Q_{0} b}+\frac{1}{Q_{0}} C_{e}
$$

where $C_{\mathrm{e}}$ is the equilibrium concentration of the adsorbate $(\mathrm{mg} / \mathrm{L}), q_{\mathrm{e}}$ is the amount of adsorbate adsorbed per unit mass of adsorbent ( $\mathrm{mg} / \mathrm{g}), Q_{o}$ and $b$ are Langmuir constants related to adsorption capacity and rate of adsorption, respectively. When $C_{\mathrm{e}} / q_{\mathrm{e}}$ was plotted against $C_{\mathrm{e}}$, a straight line with slope of 1/ $Q$ was obtained. The value of $Q$ was determined from the Langmuir plot at the concentration range 1 to $500 \mathrm{mg} / \mathrm{L}$ and then the $b$ value was calculated and tabulated in Table 2. The essential characteristics of the Langmuir isotherm can be expressed in terms of a dimensionless constant separation factor $\mathrm{R}_{\mathrm{L}}$ that is given in equation (3).

$$
R_{L}=\frac{1}{1+\mathrm{b} C_{0}}
$$

The values of $R_{\mathrm{L}}$ were found to be $0.385,0.769,0.417$ and 0.935 for $\mathrm{Cd}(\mathrm{II})$, $\mathrm{Cu}(\mathrm{II}), \mathrm{Zn}(\mathrm{II})$ and $\mathrm{Fe}(\mathrm{II})$, respectively suggesting the isotherm to be favorable at the concentrations studied. The Freundlich isotherm model ${ }^{34}$ considers a heterogeneous adsorption surface that has unequal available sites with different energies of adsorption and can be represented by equation (4).

$$
\mathrm{h} q_{e}=\mathrm{h} K_{f}+\frac{1}{n}\left(\operatorname{In} C_{e}\right)
$$

where $C_{\mathrm{e}}$ is the equilibrium concentration of the adsorbate $(\mathrm{mg} / \mathrm{L}), q_{e}$ is the amount of adsorbate adsorbed per unit mass of adsorbent $(\mathrm{mg} / \mathrm{g}), K_{f}$ and $n$ are Freundlich constants. The Freundlich constants were derived from the slopes and intercepts of $\log \mathrm{q}_{\mathrm{e}}$ versus $\log \mathrm{C}_{\mathrm{e}}$ and are presented in Table 2. $K$ can be defined as the adsorption capacity that represents the quantity of metal ions adsorbed onto the fibers for a unit equilibrium concentration and value of $n>1$ giving an indication of favorability of the adsorption process ${ }^{35}$. In this work, it is found that $K_{\mathrm{f}}$, increased in the order of $\mathrm{Zn}$ (II) $(1.74 \mathrm{mg} / \mathrm{g})<\mathrm{Cu}$ (II) $(2.68 \mathrm{mg} / \mathrm{g})<\mathrm{Fe}$ (II) $(6.85 \mathrm{mg} / \mathrm{g})<\mathrm{Cd}(\mathrm{II})(8.49 \mathrm{mg} / \mathrm{g})$ and the value of $n$ to be $1.016,1.036,1.138$ and 1.149 for $\mathrm{Zn}(\mathrm{II}), \mathrm{Cu}(\mathrm{II}), \mathrm{Fe}(\mathrm{II})$ and $\mathrm{Cd}(\mathrm{II})$, respectively. As seen from the Table 2, a high regression correlation coefficient, $\mathrm{R}^{2}$, was shown by the Freundlich model for all the metal ions. This indicates that the Freundlich model is very suitable for describing the sorption equilibrium of the metal ions by the BTF. When the linearity of the plots of the Freundlich and Langmuir models was compared, it is found that the former has a better fit. Thus it is reasonable to conclude that the adsorption of the metal ions on the fibers that consist of heterogeneous adsorption sites that are very similar to each other in respect of adsorption phenomenon.

Table 2: Langmuir and Freundlich isotherm constants and correlation coefficients for biosorption of $\mathrm{Cd}(\mathrm{II}), \mathrm{Cu}(\mathrm{II}), \mathrm{Fe}(\mathrm{II})$ and $\mathrm{Zn}(\mathrm{II})$ at ambient temperature $\left(25^{\circ} \mathrm{C}\right)$.

\begin{tabular}{|l|l|l|l|l|l|}
\hline Isotherms & \multicolumn{5}{|c|}{ Metal ions } \\
\hline Langmuir & & $\mathrm{Cd}(\mathrm{II})$ & $\mathrm{Cu}(\mathrm{II})$ & $\mathrm{Fe}(\mathrm{II})$ & $\mathrm{Zn}(\mathrm{II})$ \\
\hline $\mathrm{Q}_{0}(\mathrm{mg} / \mathrm{g})$ & & 71.43 & 63.69 & 54.35 & 263.15 \\
\hline $\mathrm{b}(\mathrm{mg} / \mathrm{L})$ & & 0.16 & 0.03 & 0.14 & 0.007 \\
\hline $\mathrm{R}^{2}$ & & 0.891 & 0.747 & 0.991 & 0.978 \\
\hline & & & & \\
\hline Freundlich & & & & & \\
\hline $\mathrm{K}_{\mathrm{f}}(\mathrm{mg} / \mathrm{g})$ & & 8.49 & 2.68 & 6.58 & 1.74 \\
\hline $\mathrm{n}$ & 1.149 & 1.036 & 1.138 & 1.016 \\
\hline $\mathrm{R}^{2}$ & 0.997 & 0.999 & 0.997 & 0.998 \\
\hline
\end{tabular}

\section{Adsorption Kinetics}

Two simplified kinetic models were adopted to examine the mechanism of the adsorption process. First, the kinetics of adsorption was analyzed by the Langergren pseudo-first-order equation ${ }^{36}$ as depicted in equation (5).

$$
\log \left(q_{e}-q_{t}\right)=\log q_{e}-\frac{k_{1} t}{2.303}
$$

where $q_{e}$ and $q_{t}$ are the amounts of the metals adsorbed $(\mathrm{mg} / \mathrm{g})$ at 
equilibrium and at time $t(\mathrm{~min})$, respectively, and $k_{1}\left(\mathrm{~min}^{-1}\right)$ is the rate constant adsorption. Values of $k_{1}$ at ambient temperature were calculated from the plots of $\log \left(q_{\mathrm{e}}-q_{\mathrm{t}}\right)$ versus $t$ for an concentration of $10 \mathrm{mg} / \mathrm{L}$ for the metals. The set of $R^{2}$ values obtained were poor and the experimental $q$ values did not agree with the calculated values obtained from the linear plots (Table 3). On the other hand, the pseudo-second-order equation based on equilibrium adsorption ${ }^{37}$ is expressed as equation (6):

$$
\frac{t}{q_{t}}=\frac{1}{k_{2} q_{e}^{2}}+\frac{1}{q_{e}} t
$$

where $k_{2}(\mathrm{~g} / \mathrm{mg} \mathrm{min})$ is the rate constant of second-order adsorption. The linear plot of $t / q_{t}$ versus $t$ at ambient temperature yielded set of $R^{2}$ values that are greater than 0.999 for all the metal at $10 \mathrm{mg} / \mathrm{L}$. It also showed a good agreement between the experimental and the calculated $q_{\mathrm{e}}$ values (Table 3), indicating the applicability of this model to describe the adsorption process of the metals onto the fibers.

Table 3: Comparison of the pseudo-first-order, pseudo-second-order adsorption rate constants and calculated and experimental $\mathrm{q}_{\mathrm{e}}$ values obtained for a concentration of $10 \mathrm{mg} / \mathrm{L}$ of $\mathrm{Cd}(\mathrm{II}), \mathrm{Cu}(\mathrm{II}), \mathrm{Fe}(\mathrm{II})$ and $\mathrm{Zn}(\mathrm{II})$.

\begin{tabular}{|c|c|c|c|c|c|c|c|c|}
\hline \multirow{2}{*}{ Metal Ions } & \multirow{2}{*}{$\begin{array}{l}\text { Concentrations } \\
(\mathrm{mg} / \mathrm{L})\end{array}$} & \multirow{2}{*}{$\mathrm{q}_{\mathrm{e}(\operatorname{Exp})}$} & \multicolumn{3}{|c|}{ Pseudo First Order Kinetic Model } & \multicolumn{3}{|c|}{ Pseudo Second Order Kinetic Model } \\
\hline & & & $k_{1}$ & $\mathrm{q}_{\mathrm{e}(\text { (Cal) }}$ & $\mathrm{R}^{2}$ & $k_{2}$ & $q_{e(\text { Cal })}$ & $\mathrm{R}^{2}$ \\
\hline $\mathrm{Cu}(\mathrm{II})$ & 10 & 2.390 & 0.033 & 0.142 & 0.978 & 0.63 & 2.284 & 0.999 \\
\hline $\mathrm{Fe}(\mathrm{II})$ & 10 & 2.415 & 0.015 & 0.030 & 0.941 & 3.54 & 2.409 & 0.999 \\
\hline $\mathrm{Zn}(\mathrm{II})$ & 10 & 2.181 & 0.038 & 0.084 & 0.918 & 1.16 & 2.186 & 1.000 \\
\hline
\end{tabular}

\section{Adsorption capacity of the modified biomass}

The adsorption experiment related to the treated banana fibers were carried out at $10 \mathrm{mg} / \mathrm{L}$ at $\mathrm{pH} 5$ using $1.0 \mathrm{~g} / \mathrm{L}$ of the fibers with an agitation speed of 150 $\mathrm{rpm}$. Mercerization and acetylation leads to the leaching out of the amorphous waxy cuticle layer. Peroxide treatment is found to fibrillate the fibers due to the leaching out of the waxes, gums and pectic substances ${ }^{12}$. Carvalho et al., ${ }^{38}$ reported that formaldehyde treatment had reduced the fiber elasticity but increased the tensile strength. The stearic acid treatment reduced the moisture content of the fiber and improved the mechanical properties of the fibers ${ }^{39}$. Acid treatment is generally used for cleaning the cell wall and replacing the natural mix of ionic species bound on the cell wall with protons and other functional groups exposing new active sites for metal removal causing increase in sorption capacity ${ }^{40-42}$. It is observed in this study (Tab.4) that all modified BTF except peroxide treated BTF showed a further slight increase in sorption capacity. The order of the sorption capacity is sulphuric acid treated BTF $>$ mercerized BTF, formaldehyde treated BTF $>$ acetylated BTF, stearic acid treated $\mathrm{BTF}>$ untreated BTF $>$ peroxide treated BTF. The slight drop in sorption capacity of the peroxide treated BTF is attributed to delignification of the fibers ${ }^{12}$ since lignin plays an important role in heavy metal adsorption ${ }^{43}$. The slight variation in the adsorption capacity of the modified BTF as compared to that of the unmodified BTF suggests the latter is by its nature already an efficient biosorbent for the removal of $\mathrm{Cd}(\mathrm{II}), \mathrm{Cu}(\mathrm{II}), \mathrm{Fe}(\mathrm{II})$ and $\mathrm{Zn}$ (II).

Table 4: $\mathrm{q}_{\mathrm{e}}$ values for untreated and treated BTF

\begin{tabular}{|c|c|c|c|c|}
\hline \multirow{2}{*}{} & \multicolumn{3}{|c|}{ Metal adsorbed, $\mathrm{q}_{\mathrm{e}}(\mathrm{mg} / \mathrm{g})$} \\
\cline { 2 - 5 } & $\mathrm{Cd}(\mathrm{II})$ & $\mathrm{Cu}(\mathrm{II})$ & $\mathrm{Fe}(\mathrm{II})$ & $\mathrm{Zn}(\mathrm{II})$ \\
\hline Untreated & 2.43 & 2.39 & 2.42 & 2.18 \\
\hline Types of Treatment & & & & \\
\hline Mercerization & 2.45 & 2.43 & 2.44 & 2.23 \\
\hline Acetylation & 2.44 & 2.41 & 2.43 & 2.19 \\
\hline Formaldehyde treatment & 2.45 & 2.41 & 2.44 & 2.21 \\
\hline Peroxide treatment & 2.41 & 2.38 & 2.40 & 2.16 \\
\hline Stearic acid treatment & 2.44 & 2.41 & 2.43 & 2.19 \\
\hline Sulphuric acid treatment & 2.48 & 2.44 & 2.45 & 2.25 \\
\hline
\end{tabular}

\section{CONCLUSION}

The present work establishes that banana pseudostem fibers, an agro-waste is an efficient biosorbent in the removal of $\mathrm{Cd}(\mathrm{II}), \mathrm{Cu}(\mathrm{II}), \mathrm{Fe}(\mathrm{II})$ and $\mathrm{Zn}$ (II) ions from aqueous solutions at $\mathrm{pH} 5$. The kinetics of sorption of the four metal ions on BTF follows a pseudo-second-order pattern. Moreover, sorption capacity is strongly dependent on the metal concentration and $\mathrm{pH}$ of solution. Banana trunk fibers are very cheap, easily available and renewable. This study revealed that this biosorbent could be used as a tool for the development of low-cost biomaterial-for the treatment of heavy metal waste. It is also worthwhile to note that by introducing new chemical sites on the biomass may not necessary aid in the adsorption capacity of BTF.

\section{ACKNOWLEDGEMENTS}

This study is partially funded by the Ministry of Science, Technology and Innovation (MOSTI) of Malaysia. The authors are also grateful to the School of Chemical Sciences, Universiti Sains Malaysia and the Faculty of Applied Sciences, AIMST University for providing the facilities to carry out this research.

\section{REFERENCES}

1. D. Sanyahumbi, J.R. Duncan, M. Zhao M, R. Hille, Biotechnol. Lett. 20, 745, (1998).

2. S.E. Manahan, Environmental Chemistry, CRC Press, Boca Raton, Florida 2004.

3. D. Kratochvil, B. Volesky, Trends Biotechnol.16, 291, (1998).

4. I. Villaescusa, N. Martinez, N. Miralles, J. Chem. Technol. Biotechnol. 75, 1, (2000).

5. K.S. Low, C.K. Lee, S.C. Liew, Process Biochem. 36, 59, (2000).

6. P.D. Johnson, M.A. Watson, J. Brown, I.A. Jefcoat, Waste Manage. 22, 471, (2002).

7. C.R.T. Tarley, M.A.Z. Arruda, Chemosphere 54, 987, (2004).

8. M. Martinez, N.Miralles, S.Hidalgo, N.Fiol, J. Hazard. Mater. B133, 203, (2006).

9. S. Schiewer, S.B. Patil, Bioresour. Technol. 99, 1896, (2008)

10. S.Senthilkumaar, S.Bharathi, D. Nithyanandhi, V. Subburam, Bioresour. Technol. 75, 163, (2000).

11. K. Bilba, M.A. Arsene, A. Ouensanga, Bioresour. Technol. 98, 58, (2007).

12. M.S. Sreekala, S.Thomas, Compos. Sci. Tech. 53, 861, (2003).

13. A.Paul, K. Joseph, S.Thomas, Compos. Sci. Tech. 57, 67, (1997).

14. S.S.Azhar, A. Ghaniey Liew, D.Suhardy, K. Farizul, M.D. Hatim, Am. J. App. Sc. 2, 1499, (2005).

15. S.S. Banerjee, M.V. Joshi, R.V. Jayaram, Chemosphere 64, 1026, (2006).

16. M. Horsfall, A.I. Spiff, Electron. J. Biotechn. 7, 313, (2004).

17. F. Pagnanelli, A.Esposito, L.Toro, F. Veglio, Water Res. 37, 627, (2003). 
18. E. Pehlivan, B.H. Yanik, G. Ahmetli, M. Pehlivan, Bioresour. Technol. 99, 3520, (2008).

19. S Schiewer, B. Volesky, Environmental Microbe-Metal Interactions (Ed: D.R Lovely), ASM Press, Washington DC, 2000

20. J.M. Tobin, D.G. Cooper, R.J. Neufeld, App. Environ. Microbiol. 47, 821, (1984).

21. S.Schiewer, B. Volesky, Environ. Sci. Technol. 29, 3049, (1995).

22. Z. Reddad, C. Gerente, Y. Andres, P. LeCloirec, Environ. Sci. Technol. 36, 2067, (2002).

23. Y. Sag, T. Kutsal, Process Biochem. 31, 561, (1996).

24. A.C.A. da Costa, S.G.F. Leite, Biotechnol. Lett. 13, 559, (1991).

25. E. Romera, F.Gonzales, A.Balleter, M.L.Blazquez, J.A. Munoz, Bioresour. Technol. 98, 3344, (2007).

26. B. Pejic, M. Vukcevic, M. Kostic, P. Skundric, J. Hazard. Mater. 164, $146,(2009)$.

27. B. Nasernejad, T. Esslam Zadeh, B. Bonakdar Pour, M. Esmaail Bygi, A. Zamani, Process Biochem. 40, 1319, (2005).

28. F.E. Okieimen, D.E. Ogbeifeur, G.N. Nwala, C.A. Kumsah, Bull. Environ. Contam. Toxicol. 34, 866, (1985).

29. S. Ricordel, S. Taha, I. Cisse, G. Dorange, Sep. Purif. Technol. 24, 389 , (2001).
30. B. Volesky, S. Schiewer, Encyclopedia of Bioprocess Technology: Fermentation, Biocatalysis, and Bioseparation (Eds: M.C. Flickinger, S.W. Drew), John Wiley \& Sons, New York, 1999.

31. N. Goyal, S.C. Jain, U.C. Banerjee, Adv. Environ. Res. 7, 311, (2003).

32. A. Saeed, M.W. Akhter, M. Iqbal, Sep. Purif. Technol. 45, 25, (2005).

33. I. Langmuir, J. Am. Chem. Soc. 40, 1361, (1918).

34. H.M.F. Freundlich, J. Phy. Chem. 57, 385, (1906).

35. B.H. Hameed, H Hakimi, Biochem. Eng. J. 39, 338, (2008).

36. Y.S. Ho, Scientometrics 59, 171, (2004).

37. Y.S. Ho, G. McKay, Resour. Conserv. Recycl. 25, 171, (1999).

38. R.A. de Carvalho, C.R.F. Grosso, Food Hydrocolloid. 8, 717, (2004).

39. K.Nattaspol, K.Narumol, P.Thirawudh, P. Chantaraporn, J. Polym. Eng. 27, 411, (2007).

40. Y.Y. Sang, J. Microbiol. Biotechnol. 14, 29, (2004).

41. Y.Y. Saug, D. Park, J.M. Park, B. Volesky, Environ. Sci. Technol. 35, 4535, (2001).

42. T.A. Davis, B. Volesky, A. Mucci, Water Res. 37, 4311, (2003).

43. M.N.M Ibrahim, W.S.W Ngah, M.S. Norliyana, W.R. Daud, Clean, 37, $80,(2009)$ 